THE CASE FOR GREATNESS 



\section{THE CASE FOR GREATNESS}

\section{Honorable Ambition and Its Critics}

\section{ROBERT FAULKNER}

Yale University Press New Haven \& London 
Copyright (C) 2007 by Yale University.

All rights reserved.

This book may not be reproduced, in whole or in part, including illustrations, in any form (beyond that copying permitted by Sections 107 and 108 of the U.S. Copyright Law and except by reviewers for the public press), without written permission from the publishers.

Designed by James J. Johnson and set in Janson type by The Composing Room of Michigan, Inc.

Printed in the United States of America.

\section{Library of Congress Cataloging-in-Publication Data}

Faulkner, Robert K., I934-

The case for greatness : honorable ambition and its critics / Robert Faulkner.

p. $\mathrm{cm}$.

Includes bibliographical references and index.

ISBN 978-0-300-I 2393-7 (alk. paper)

I. Ambition. I. Title.

BJ $1533 \cdot \mathrm{A}_{4} \cdot \mathrm{F}_{3} 82007$

I $79^{\prime} \cdot 9-\mathrm{dc} 22$

A catalogue record for this book is available from the British Library.

The paper in this book meets the guidelines for permanence and durability of the Committee on Production Guidelines for Book Longevity of the Council on Library Resources.

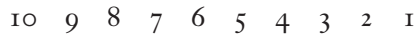




\section{To Margaret}



Mankind has never been in this position before. Without having improved appreciably in virtue or enjoying wiser guidance, it has got into its own hands the tools by which it can unfailingly accomplish its own extermination. ... It is therefore above all things important that the moral philosophy and spiritual conceptions of men and nations should hold their own amid these formidable scientific evolutions.

-Winston Churchill, Thoughts and Adventures (1932) 
